\title{
USE OF THE FIBER OPTIC BRONCHOSCOPE FOR NASOTRACHEAL INTUBATION: CASE REPORT
}

\author{
A.B. ConYers, M.B., F.F.A.R.C.S., D.H. WALLACE, M.B., F.F.A.R.C.S., \\ AND D.S. MULDEn, M.D., F.A.C.S. (C)
}

THIS IS A REPORT OF THE SUCCESSFUL USE OF THE FLEXIBLE FLBEROPTIC BRONCHOSCOFE to achieve endotracheal intubation in a difficult case. The visual control afforded by this technique ensured easy, safe and atraumatic tracheal intubation.

The patient was an adult female 43 years old who had suffered from rheumatoid arthritis since childhood and in whon repeated attempts to intuhate the trachea by the usual methods had been unsuccessful. Elective tracheostomy had been planned prior to total hip replacement, as it had previously proved extremely difficult to maintain an airway.

The particular problems presented by this patient included a full dentition with prominent incisor teeth and a foreshortened mandible. The cervical spine was rigid and no extension was possible at the atlanto-occipital joint. It was known from the previous attempts to intubate the trachea that the larynx was situated in an anterior position, and that the epiglottis was fixed close to the posterior pharyngeal wall.

\section{TECHNIQUe}

It was suggested (A.B.C.) that visualization of the glottis by means of the fiber optic instrument might permit intubation, and, following discussion between the authors it was decided to utilize the instrument as an introducer, employing the endoscopist's usual approach through the nose.

Following premedication with diazepam, surface analgesia was established by topical application and by the trans-tracheal injection of 4 per cent lidocaine, to a total dose of $4 \mathrm{ml}$, A lubricated $6.5 \mathrm{~mm}$ Portex nasal tracheal tube was passed over the well-lubricated fiber optic bronchoscope and positioned close to the control mount.

The endoscopist confirmed the posterior position of the epiglottis and commented on the notable rigidity of this foreshortened structure. The vocal cords were inspected and the glottis was easily entered. The trachea appeared normal, and the portex tube was threaded through the nose and between the vocal cords. The fiber optic bronchscope was removed and general anaesthesia was then im* mediately induced.

\section{EqUIPMENT}

A standard flexible fiber optic bronchoscope was used (Olympus Optical Co. Ltd., Model BF-5B). The features of this instrument include control of a wide

- Monteal General Hospital, Montreal. 


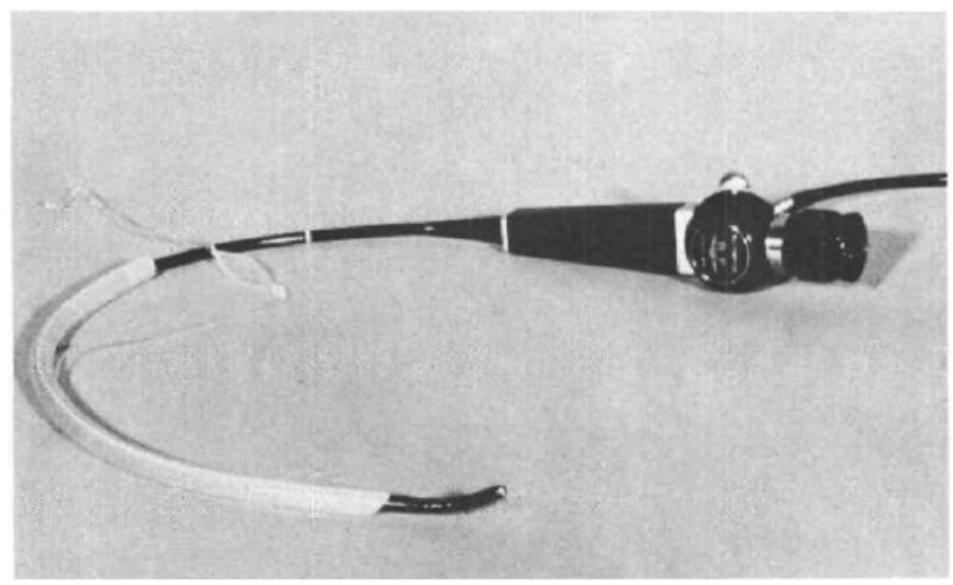

Figure 1. Portex tracheal tube fitted over the flexible fiber optic bronchoscope.

range forward viewing angle, a cold light source from optical fibers, and an objective lens giving a high degree of resolution through a useful depth of field.

The widest diameter of the instrument used is $5 \mathrm{~mm}$, allowing easy nasal or oral passage. An internal aspiration channel permits suction of secretions, administration of local anaesthesia, or collection of cytology specimens as required.

\section{Discussion}

The method used was decided upon because of the endoscopist's previous experience with the use of the instrument for bronchoscopy under local anaesthesia. Local anaesthesia was favoured for this patient in view of the known difficulties of maintaining the airway.

The nasal approach avoided the risk of damage to the instrument by inadvertent closure of the teeth. It provided a good angle of approach in this case because of the rigidity and position of the epiglottis.

Subsequently the instrument has been successfully used in the management of other cases, and it is our intention to make a further report of these, including the oral approach.

Voici le cumpte rendu de l'utilisation avec succès d'un bronchoscope flexible fibreoptique pour pratiquer une intubation trachéale dans un cas difficile. Cette technique assure un contrồle visuel qui rend l'intubation trachéale facile, atraumatique et de toute sécurité.

Il s'agissait d'une malade de 43 ans qui avait souffert d'arthrite rhumatoïde depuis son enfance et chez qui on avait essayé, à plusieurs reprises, mais sans succès, de pratiquer une intubation trachéale par les méthodes usuelles. Avant de tenter d'installer une prothèse totale de la hanche, on avait songé à pratiquer une tra- 
chéostomie élective, car antérieurement, il s'était avéré très difficile de maintenír libres ses voies respiratoires.

Parmi les problèmes particuliers que présentait cette malade, citons: "1" une dentition complète avec des incisives proéminentes et un mandibule court. " 2 " La colonne cervicale était rigide et aucune extension n'était possible à l'articulation atlas occipitale. " 3 " A la suitc de tentatives antérieures d'intubation trachéale, il était connu que le larynx était en position antérieure et que l'épiglotte était fixée en position fermée à la paroi postérieure du pharynx.

\section{TeGhNique}

Il a été suggéré $(A, B, C$, de visualiser la glotte par un instrument fibre-optique et qu'ainsi, il serait peut-être possible de pratiquer l'intubation trachéale, puis, après discussion entre les auteurs, il a été décidé d'utiliser l'instrument conme guide et de se servir de l'approche habituel de l'endoscopiste en passant par le nez.

Après prémédication au diazepam, analgésie de surface par application Iocale, et après une injection transtrachéale de 4 pour cent de lidocaine, au total $4 \mathrm{ml}$, un tube portex $6.5 \mathrm{~mm}$ pour intubation nasale a été bien lubrifié et monté sur le bronchoscope fibreoptique, lui aussi bien lubrifié et placé près du point de contrôle.

L'endoscopiste a confirmé la position de l'épiglotte et cette grande rigidité du mandibule court. Les cordes vocales ont été examinées et l'instrument introduit facilement dans la glotte. La trachée a paru normale, alors le tube portex a été descendu entre les cordes vocales en passant par le nez. Le bronchoscope a été retiré et, aussitôt, l'anesthésie générale a commencé.

\section{Outrllage}

Nous avons utilisé un bronchoscope flexible standard fibrenptique (Olympus Optical Co. Ltd., Model BF-5B); parmi les possibilités de cet instrument, mentionnons une visibilité de grande étendue en avant et en latéral, une source de lưmière froide due à la fibreoptique et un objectif permettant un grand relâchement à une profondeur utile.

Le plus grand diamètre de lappareil employé est de $5 \mathrm{~mm}$ ce qui rend facilement possible le passage par le nez ou par la bouche. Une canalisation centrale permet d'aspirer les sécrétions, d'administrer une anesthésie locale ou de prélever des échantillons pour cytologie si nécessaire.

\section{Discussion}

Nous en sommes venus à choisir la technique décrite à cause de l'expérience antérieure de l'endoscopiste avec l'emploi du bronchoscope sous anesthésie locale. Nous avons préféré l'anesthésie locale chez cette malade à cause des difficultés de maintenir libres les voies respiratoires.

La voie nasale évitait le risque d'endommager l'instrument par la fermeture accidentelle des dents chez cette malade, à cause de la rigidité et de la position de l'épiglotte, cette voie offrait un bon angle.

Ultérieurement, pour d'autres cas, l'instrument a été employé avec succès et nous avons l'intention de raconter d'autres cas, 5 compris par la voie orale. 